\title{
KANDUNGAN BAHAN KERING TANPA LEMAK (BKTL) SUSU SAPI PERAH FRIESIAN HOLSTEIN AKIBAT PEMBERIAN PAKAN YANG MENGANDUNG TEPUNG KATU (Sauropus androgynus (L.) Merr) YANG BERBEDA
}

\author{
Roosena Yusuf \\ Jurusan Peternakan Fakultas Pertanian Universitas Mulawarman \\ Jalan Tanah Grogot Kampus Gunung Kelua Samarinda Kaltim
}

\begin{abstract}
The purpose of this research was to determine the effect of increasing the provision shrub on milk solid non fat content of Friesian Holstein dairy cattle. Research material used was 9 Friesian Holstein dairy cattle on the second lactation at the sixth month lactation with body weight $(B W)$ of $436 \pm 48.67 \mathrm{~kg}$, milk production of $8.86 \pm 1.2$ liter. Single factor experiment arranged in Complete Random Design with 3 treatments, each replicated for three times, was used in this experiment. The cows were fed with concentrate feed (Crude Protein $=13.42 \%$ ) added by shrub flour at three levels of $0 \% \mathrm{BW}\left(t_{0}\right), 0.03 \% \mathrm{BW}\left(t_{1}\right), 0.05 \% \mathrm{BW}\left(t_{2}\right)$, and maize straw as forage at each level of shrub flour in the concentrate. The ratio between concentrate and forage 60\%:40\%. Obtained data was calculated by ANOVA. Results showed that the average consumption of dry matter feed determined at $t_{0}, t_{1}$, and $t_{2}$ were $10.22 ; 10.70$ and $11.63 \mathrm{~kg} / \mathrm{cow} /$ day $(P>0.05)$, respectively. The average of milk solid non fat of $t_{0}, t_{1}$ and $t_{2}$ were $0.672 ; 0.811$ and $0.864 \mathrm{~kg} /$ liter $(P>0.05)$, respectively. However shrub flour providing in the concentrate until level of $0.05 \%$ BW did not increase milk solid non fat of Friesian Holstein dairy cattle milk solid non fat.
\end{abstract}

Keywords : milk solid non fat, Friesian Holstein dairy cattle, shrub

\section{PENDAHULUAN}

Susu berperan penting dalam memenuhi kebutuhan protein hewani bagi masyarakat Indonesia. Permintaan susu dari waktu ke waktu semakin meningkat, hal ini terjadi karena jumlah penduduk yang terus meningkat dan pendapatan masyarakat juga meningkat. Produksi susu secara nasional belum dapat mencukupi kebutuhan susu dalam negeri karena permintaan susu secara nasional dari segi kuantitas mungkin dapat terpenuhi tetapi secara kualitas belum dapat memenuhi keinginan produsen susu dan konsumen, sehingga produksi susu dalam negeri baru dapat diterima sebanyak $40 \%$ sedangkan $60 \%$ lainnya dipenuhi dari susu impor. Ketidakmampuan dalam memenuhi permintaan susu tersebut dikarenakan produktivitas sapi perah Indonesia rata-rata masih rendah baik secara kuantitas maupun kualitas.

Peningkatan produktivitas sapi perah dapat diperoleh dengan cara melakukan suatu terobosan, diantaranya dengan cara memberikan daun katu (Sauropus androgynus (L.) Merr) yang telah dikenal dapat meningkatkan produksi susu ibu. Daun katu dipandang sebagai pakan suplemen atau pakan tambahan yang diharapkan dapat memberikan dampak positif untuk meningkatkan kualitas dan kuantitas susu sapi perah. Pemberian katu dalam bentuk bubuk dan ekstrak dapat meningkatkan produksi susu pada domba 
Kandungan bahan kering tanpa lemak (bktl) susu sapi perah friesian holstein akibat pemberian pakan yang mengandung tepung katu (sauropus androgynus (l.) Merr) yang berbeda

betina (Suprayogi, 2000). Sampai saat ini belum ada bukti yang melaporkan bahwa pemberian daun katu pada sapi perah dapat meningkatkan kuantitas dan kualitas susu, sehingga perlu dilakukan suatu penelitian untuk mengetahui hal ini.

Katu mengandung zat kimia oxocyclopenthyl yang berperan dalam merangsang aktivitas metabolik dan pertumbuhan mikroba rumen. Jika jumlah mikroba rumen meningkat, maka fermentasi pakan juga lebih optimal sehingga "Volatile Fatty Acids" (VFA) yang dihasilkan juga meningkat. VFA terdiri dari asam asetat, asam propionat dan asam butirat. Salah satu produk VFA adalah asam propionat yang selanjutnya setelah proses glukoneogenesis di hati akan terbentuk glukosa yang akan dibawa darah ke ambing. Glukosa tersebut merupakan prekursor laktosa susu. Laktosa di dalam susu berfungsi untuk mengikat air. VFA yang dihasilkan meningkat maka laktosa susu juga meningkat, sehingga produksi susu yang dihasilkan juga meningkat. Jadi pemberian katu dapat memberikan dampak positif untuk meningkatkan konsumsi bahan kering ransum dan BKTL susu.

\section{METODE}

\section{Materi Penelitian}

Sapi perah Friesian Holstein sejumlah 9 ekor, dengan kriteria tahun laktasi kedua, bulan laktasi keenam dengan bobot badan rata-rata $436 \pm 48,67 \mathrm{~kg}$, rata-rata produksi susu 8,86 $\pm 1,20$ liter; ransum sapi perah berupa konsentrat dan jerami jagung dengan protein kasar 13,42\%; tepung katu. Imbangan hijauan dengan konsentrat yang digunakan adalah 40\%:60\%.

Ransum sapi penelitian yang digunakan terdiri dari hijauan berupa jerami jagung dan konsentrat. Konsentrat yang digunakan adalah konsentrat hasil formulasi sendiri dari CV Argasari.

Peralatan yang digunakan dalam penelitian ini, yaitu timbangan ternak digital merk Iconik berkapasitas $1000 \mathrm{~kg}$ dengan ketelitian $0,5 \mathrm{~kg}$, timbangan pakan digital berkapasitas $6 \mathrm{~kg}$ dengan ketelitian 0,002 $\mathrm{kg}$, timbangan pakan merk SSS dengan kapasitas $300 \mathrm{~kg}$ dengan ketelitian $100 \mathrm{~g}$, takaran susu merk Scarlet berkapasitas 2 liter dengan ketelitian $10 \mathrm{~mL}$, kantong plastik untuk sampel susu.

Rancangan percobaan yang digunakan adalah Rancangan Acak Lengkap (RAL) menggunakan uji F (Hanafiah, 1994). Jumlah perlakuan yang diterapkan sebanyak 3 perlakuan pemberian katu masing-masing dengan 3 ulangan.

Perlakuan yang diberikan dalam penelitian adalah sebagai berikut :

$\mathrm{t}_{0} \quad=$ Jerami jagung + konsentrat

$\mathrm{t}_{1}=$ Jerami jagung + konsentrat + tepung katu $(0,03 \%$ Bobot Badan)

$\mathrm{t}_{2}=$ Jerami jagung + konsentrat + tepung katu $(0,05 \%$ Bobot Badan)

\section{Prosedur Penelitian}

Tahap penelitian yang dilakukan meliputi tahap persiapan, tahap pendahuluan dan tahap pengambilan data. Kegiatan yang dilakukan pada tahap persiapan adalah pemilihan sapi sebagai materi penelitian, persiapan kandang dan peralatan. Kegiatan yang dilakukan pada tahap pendahuluan adalah penimbangan ternak untuk mengetahui bobot badan sebagai dasar penentuan jumlah pakan yang akan diberikan, pengacakan ternak terhadap perlakuan pakan dan penempatan ternak dalam kandang.

Tahap pendahuluan dilakukan selama 1 minggu. Sapi penelitian diberikan ransum 
Kandungan bahan kering tanpa lemak (bktl) susu sapi perah friesian holstein akibat pemberian pakan yang mengandung tepung katu (sauropus androgynus (l.) Merr) yang berbeda

perlakuan yang bertujuan untuk menghilangkan pengaruh dari ransum terdahulu. Sapi perah penelitian dibagi menjadi 3 perlakuan dan masing-masing terdiri dari 3 ulangan. Tahap pengambilan data dilakukan selama 4 minggu. Kegiatan yang dilakukan selama tahap pengambilan data adalah penimbangan bobot badan ternak, pemberian pakan, dan pengambilan data.

Pemberian pakan dalam bentuk segar diberikan secara ad libitum sesuai dengan kebutuhan yang dihitung dalam bahan kering berdasarkan bobot badan (Tabel 3 dan 4).

Air minum diberikan secara ad libitum. Penimbangan sisa pakan dilakukan setiap akan dilakukan penggantian pakan. Penimbangan bobot badan dilakukan setiap 1 minggu sekali pada pagi hari setelah pemerahan pagi sebelum diberi pakan. Parameter yang diamati meliputi konsumsi bahan kering dan bahan kering tanpa lemak susu.

Table 1. Nutritional Content of Cow Feed Materials Research

\begin{tabular}{llllllll}
\hline Feed (\%) & DM & CP & CFat & CFi & Ca & P & TDN \\
\hline Maize straw & 28.380 & 12.033 & 2.977 & 27.167 & 3.688 & 5.164 & 28.175 \\
Concentrate & 84.155 & 14.093 & 8.639 & 19.076 & 1.613 & 3.240 & 69.798 \\
Shrub flour & 90.400 & 30.935 & 4.851 & 12.417 & 1.847 & 1.100 & 92.824 \\
\hline
\end{tabular}

Note : Dry Matter (DM); Crude Protein (CP); Crude Fat (CFat); Crude Fiber (CFi); Calcium (Ca); Phosphor (P); Total Digestible Nutrient (TDN)

Table 2. Ration composition and nutrition content applied in this research

\begin{tabular}{|c|c|c|c|}
\hline \multirow{2}{*}{ Type of feed and nutrition } & \multicolumn{3}{|c|}{ Ration composition and nutrition content (\%) } \\
\hline & $\mathrm{t}_{0}$ & $t_{1}$ & $\mathrm{t}_{2}$ \\
\hline * Maize straw & 40 & 40 & 40 \\
\hline * Concentrate & 60 & 60 & 60 \\
\hline * Shrub Flour & 0 & $0.03 \mathrm{BB}$ & $0.05 \mathrm{BB}$ \\
\hline \multicolumn{4}{|l|}{ Nutrition: } \\
\hline * Crude protein & 13.27 & 13.43 & 13.56 \\
\hline * Crude fiber & 22.30 & 22.23 & 22.14 \\
\hline * Crude fat & 6.39 & 6.35 & 6.36 \\
\hline * Calcium & 2.43 & 2.43 & 2.42 \\
\hline * Phosphor & 4.00 & 3.98 & 3.96 \\
\hline * TDN & 53.24 & 53.47 & 53.88 \\
\hline
\end{tabular}

Note: $t_{0}=$ Maize straw + Concentrate $; t_{1}=$ Maize straw + Concentrate + Shrub flour $(0.03 \%$ BW $) ; t_{2}=$ Maize straw + Concentrate + Shrub flour $(0.05 \% \mathrm{BW})$ 
Kandungan bahan kering tanpa lemak (bktl) susu sapi perah friesian holstein akibat pemberian pakan yang mengandung tepung katu (sauropus androgynus (l.) Merr) yang berbeda

Table 3. Nutrition content of minimal dietary feed requirements of dairy cattle at different body weight levels and in milk production for different level of fat

\begin{tabular}{lllll}
\hline \multirow{2}{*}{ Body Weight $(\mathrm{kg})$} & \multicolumn{4}{l}{ Nutrition Content $(\mathrm{kg})$} \\
\cline { 2 - 5 } & $\begin{array}{l}\text { Total Digestible } \\
\text { Nutrient }\end{array}$ & $\begin{array}{l}\text { Crude } \\
\text { Protein }\end{array}$ & Calcium & Phosphor \\
\hline 350 & 2.85 & 0.341 & 0.014 & 0.011 \\
400 & 3.15 & 0.373 & 0.015 & 0.013 \\
450 & 3.44 & 0.403 & 0.017 & 0.014 \\
\hline Fat content in Milk (\%) & & & & \\
\hline 2.5 & 0.260 & 0.072 & 0.0024 & 0.00165 \\
\hline 3.0 & 0.282 & 0.077 & 0.0025 & 0.00170 \\
\hline 3.5 & 0.304 & 0.082 & 0.0026 & 0.00175 \\
\hline
\end{tabular}

Table 4. $\quad$ Dry matter requirements of dairy cattle at lactation for different milk production level and body weight

\begin{tabular}{lllccc}
\hline Milk Production in 4\% & Fat & \multicolumn{4}{l}{ Dry matter at different body weight $(\mathrm{kg})$} \\
\cline { 3 - 6 } Content Milk (kg) & & 400 & 450 & 500 & 550 \\
\hline 5 & & 2.20 & 2.15 & 2.10 & 2.05 \\
10 & 2.50 & 2.40 & 2.30 & 2.25 \\
15 & & 2.80 & 2.65 & 2.50 & 2.45 \\
\hline
\end{tabular}

\section{HASIL DAN PEMBAHASAN}

\section{Konsumsi Bahan Kering (BK) Ransum}

Rata-rata konsumsi BK ransum sapi penelitian antara perlakuan $t_{0}, t_{1}$ dan $t_{2}$ masing-masing sebesar 10,$22 ; 10,70$ dan $11,63 \mathrm{~kg} / \mathrm{ekor} / \mathrm{hari}$. Selisih rata-rata konsumsi $B K$ ransum antara $t_{0}$ dan $t_{1}$ sebesar $0,48 \mathrm{~kg}$, antara $t_{0}$ dan $t_{2}$ sebesar $1,41 \mathrm{~kg}$ dan antara $t_{1}$ dan $t_{2}$ sebesar $0,93 \mathrm{~kg}$. Konsumsi BK ransum yang tidak berbeda nyata ini disebabkan oleh pemberian katu pada level $0,03 \%$ dan $0,05 \%$ bobot badan belum mampu memberikan kontribusi yang cukup terhadap peningkatan komposisi zat gizi ransum terutama kadar protein kasar ransum, sehingga respon semua perlakuan terhadap konsumsi BK ransum juga relatif sama. Rata-rata kadar protein kasar ransum untuk perlakuan $t_{0}, t_{1}$ dan $t_{2}$ relatif sama yaitu $13,27 \% ; 13,43 \%$ dan $13,56 \%$ BK dan diduga tingkat palatabilitas pakan juga sama, sehingga respon terhadap konsumsi BK ransum juga sama.

Pemberian katu pada level $0,03 \%$ dan $0,05 \%$ BB diduga belum mampu memberikan pengaruh yang nyata terhadap konsumsi bahan kering ransum. Hal ini disebabkan oleh asam cyclopenthyl $\left(\mathrm{C}_{9} \mathrm{H}_{12} \mathrm{O}_{3}\right)$ yang terkandung dalam katu sebagai pemicu utama yang merangsang aktivitas metabolik dan pertumbuhan mikroba rumen, diduga belum mampu memberikan pengaruh yang nyata terhadap kerjasama dan hubungan saling mempengaruhi antar mikroba rumen dalam jalur siklus asam sitrat, akibatnya fermentasi bahan organik oleh mikroba rumen juga tidak berbeda nyata sehingga menyebabkan efisiensi pemanfaatan 
Kandungan bahan kering tanpa lemak (bktl) susu sapi perah friesian holstein akibat pemberian pakan yang mengandung tepung katu (sauropus androgynus (l.) Merr) yang berbeda

ransum dan respon terhadap konsumsi BK ransum juga tidak berbeda nyata. Asam 3, 4-dimethyl-2-oxocyclopent-3-enylacetat dapat dihidrolisis melalui proses fermentasi dalam rumen menjadi asam asetat (Suprayogi, 2000). Asam asetat berperan dalam mempengaruhi aktivitas metabolisme dan pertumbuhan mikroba dalam rumen. Asam asetat dalam fungsinya sebagai pemicu utama (trigger) dalam menstimulasi metabolisme mikroba rumen dengan lebih mengaktifkan siklus asam sitrat dimana asetat sebelumnya telah diubah menjadi Acetil CoA untuk memproduksi Adenosin Tri Phosphat (ATP). Produk berupa ATP yang dihasilkan inilah yang digunakan oleh mikroba rumen sebagai sumber energi untuk aktivitas fermentasi di dalam rumen. Asam asetat hasil dari fermentasi katu dalam rumen belum memberikan tambahan asam asetat yang cukup berarti pada sapi perlakuan yang diberi level katu yang berbeda.

Table 5. The Average Consumption of Dry Matter Feed of Research Cow (kg/cow/day)

\begin{tabular}{clll}
\hline \hline \multirow{2}{*}{ Replication } & \multicolumn{2}{l}{ Treatment $(\mathrm{kg} /$ cow/day $)$} & $\mathrm{t}_{2}$ \\
\cline { 2 - 4 } & $\mathrm{t}_{0}$ & $\mathrm{t}_{1}$ & 11.54 \\
1 & 8.91 & 11.17 & 11.44 \\
3 & 12.61 & 9.17 & 11.91 \\
\hline Average & 9.14 & 11.73 & 11.63
\end{tabular}

Note : The average values showed no significant differences $(\mathrm{P}>0.05)$

Adenosin Tri Phosphat merupakan sumber energi utama untuk hidup dan pertumbuhan bagi mikroba rumen (Suprayogi, 2000). Ketersediaan ATP sebagai sumber energi akan menjamin aktivitas dan pertumbuhan mikroba rumen. Jika aktivitas mikroba rumen meningkat maka tingkat degradasi pakan juga akan meningkat dan secara langsung juga akan berpengaruh terhadap laju pakan. Laju pakan berhubungan dengan konsumsi pakan, semakin cepat laju pakan maka tingkat konsumsi akan meningkat. Konsumsi pakan seekor sapi dipengaruhi oleh berbagai faktor yang kompleks meliputi faktor hewannya sendiri, pakan yang diberikan dan lingkungan tempat hewan tersebut dipelihara. Jadi jika kondisi fisik, fisiologis ternak, lingkungan tempat ternak dipelihara dan kualitas pakan yang diberikan seragam akan menyebabkan tingkat konsumsi yang sama pula (Parakkasi, 1999). Salah satu pengaruh kondisi fisiologis ternak adalah $\mathrm{pH}$ rumen. $\mathrm{pH}$ rumen sekitar 6,7 merupakan salah satu syarat agar fermentasi oleh mikroba rumen berjalan normal (Soebarinoto et al., 1991). Menurut Arora (1989), pH rumen yang kondusif adalah 6,8 , sedangkan $\mathrm{pH}$ rumen pada sapi penelitian berkisar antara $8-9$. Hal ini menunjukkan bahwa kondisi rumen yang tidak kondusif dapat mengakibatkan kinerja mikroba rumen tidak optimal dan proses fermentasi pada rumen tidak berjalan dengan baik.

Komposisi kimia pakan akan mempengaruhi gerak laju digesta yang juga mempengaruhi konsumsi pakan (Parakkasi, 1999). Katu mengandung saponin dan tannin yaitu protein terproteksi yang mengakibatkan terjadinya "by passing" sehingga tidak dapat dimanfaatkan mikroba rumen untuk proliferasi akibat kinerja 
Kandungan bahan kering tanpa lemak (bktl) susu sapi perah friesian holstein akibat pemberian pakan yang mengandung tepung katu (sauropus androgynus (l.) Merr) yang berbeda

mikroba rumen tidak optimal. Katu mengandung saponin dan tanin yaitu protein yang terproteksi dimana mengakibatkan terjadinya "by passing" atau protein yang lolos degradasi oleh mikroba rumen. Lebih lanjut dijelaskan mikroba rumen membutuhkan $82 \% \quad \mathrm{NH}_{3}$ yang diubah dari protein untuk proliferasi dalam proses pendegradasian protein (Santosa et al. , 1997).

\section{Kandungan BKTL Susu}

Rata-rata kandungan BKTL susu sapi penelitian antara perlakuan $t_{0}, t_{1}$ dan $t_{2}$ masing-masing sebesar 0,$672 ; 0,811$ dan $0,864 \mathrm{~kg} / \mathrm{liter}$. Selisih rata-rata kandungan BKTL susu antara $t_{0}$ dengan $t_{1}$ sebesar $0,139 \mathrm{~kg}$, antara $\mathrm{t}_{0}$ dengan $\mathrm{t}_{2}$ sebesar 0,192 $\mathrm{kg}$ dan antara $\mathrm{t}_{1}$ dengan $\mathrm{t}_{2}$ sebesar $0,053 \mathrm{~kg}$. Hasil analisis statistik menunjukkan bahwa rata-ratan kandungan $\mathrm{BKTL}$ susu antara $\mathrm{t}_{0}$, $\mathrm{t}_{1}$ dan $\mathrm{t}_{2}$ tidak menunjukkan perbedaan yang nyata $(\mathrm{P}>0,05)$. Kandungan BKTL susu yang tidak berbeda nyata ini disebabkan oleh pemberian katu pada level $0,03 \%$ dan $0,05 \%$ BB belum mampu memberikan kontribusi yang cukup terhadap peningkatan komposisi nutrisi ransum terutama konsumsi bahan kasar (BK) ransum. Rata-rata konsumsi BK ransum pada perlakuan $t_{0}, t_{1}$ dan $t_{2}$ yaitu masing-masing adalah 10,22; 10,70 dan $11,63 \mathrm{~kg} / \mathrm{ekor} /$ hari. Konsumsi BK ransum yang hampir sama akan mempengaruhi tampilan BK susu, protein susu dan laktosa susu yang hampir sama juga, hal ini sesuai dengan pendapat Prihadi (1996) yaitu penambahan protein dalam pakan diatas kebutuhan normal tidak akan meningkatkan produksi susu dan hanya sedikit sekali meningkatkan kandungan BKTL susu sekitar $0,2 \%$.

Table 6. The Average Content of Milk Solid Non Fat of Cow (kg/cow/day)

\begin{tabular}{clll}
\hline \hline \multirow{2}{*}{ Replication } & \multicolumn{2}{l}{ Treatment (kg/cow/day) } & \\
\cline { 2 - 4 } & $\mathrm{t}_{0}$ & $\mathrm{t}_{1}$ & $\mathrm{t}_{2}$ \\
\hline & & & 0.753 \\
2 & 0.698 & 0.887 & 0.958 \\
3 & 0.607 & 0.753 & 0.881 \\
\hline Average & 0.712 & 0.794 & 0.864
\end{tabular}

Note : The average values showed no significant differences $(\mathrm{P}>0.05)$

Bahan kering ransum yang dikonsumsi sapi perah tersebut di dalam rumen akan difermentasi oleh mikroba rumen. Apabila BK ransum banyak mengandung protein maka akan membantu mikroba rumen untuk proliferasi atau perbanyakan jumlah. Jika jumlah mikroba rumennya banyak maka proses fermentasi di dalam rumen lebih optimal sehingga produk VFA yang dihasilkan juga optimal. VFA akan digunakan untuk proses sintesis produksi susu. Anggorodi (1994) menyebutkan bahwa kenaikan konsumsi pakan akan menyebabkan naiknya kadar BKTL susu. Setiap kenaikan BKTL susu akan diikuti dengan kenaikan BK susu (Sindoeredjo, 1960). Susu terdiri dari BK susu dan air, sedangkan BKsusu terdiri dari BKTL susu dan BK lemak susu. BKTL susu terdiri dari protein susu, laktosa susu, vitamin dan mineral (Hadiwiyoto, 1994). Dijelaskan lebih lanjut bahwa sejak dari awal 
Kandungan bahan kering tanpa lemak (bktl) susu sapi perah friesian holstein akibat pemberian pakan yang mengandung tepung katu (sauropus androgynus (l.) Merr) yang berbeda

konsumsi BK ransum tidak berbeda nyata, maka VFA yang terbentuk juga tidak berbeda nyata, sehingga produksi susu juga tidak berbeda nyata. Produksi susu tidak berbeda nyata, maka protein susu yang terbentuk tidak berbeda nyata, selain itu laktosa susu juga tidak berbeda nyata. Hal ini mengakibatkan kandungan BKTL susu juga tidak berbeda nyata.

\section{KESIMPULAN}

Pemberian tepung katu atau Sauropus androgynus (L.) Merr sampai taraf 0,05\% dari bobot badan sapi perah Friesian Holstein dengan kriteria tahun laktasi kedua, bulan laktasi keenam dengan bobot badan rata-rata $436 \pm 48,67 \mathrm{~kg}$ serta rata-rata produksi susu $8,86 \pm 1,20$ liter tidak mempengaruhi konsumsi bahan kering ransum dan kandungan BKTL susu.

\section{DAFTAR PUSTAKA}

1. Anggorodi, R. 1994. Ilmu Makanan Ternak Umum. Cetakan V. PT. Gramedia, Jakarta.

2. Arora SP (1989) Pencernaan Mikroba pada Ruminansia. Gadjah Mada University Press, Yogyakarta. (Diterjemahkan oleh R. Murwani).

3. Hadiwiyoto, S. 1994. Teori dan Prosedur Pengujian Mutu Susu dan Hasil Olahannya. Edisi Ke-2, Cetakan II, Liberty, Yogyakarta.

4. Hanafiah KA (1994) Rancangan Percobaan Teori dan Aplikasi. PT. Raja Gramafindo Persada, Jakarta.
5. Parakkasi A (1999) Ilmu Nutrisi dan Makanan Ternak Ruminansia. Penerbit Universitas Indonesia (UI-Press), Jakarta.

6. Prihadi, S. 1996. Tata Laksana dan Produksi Ternak Perah. Fakultas Pertanian Universitas Wangsamanggala, Yogyakarta. (Tidak dipublikasikan).

7. Santosa SO, Hasanah M, Yuliani S, Setiawati A, Mariana Y, Handoko T, Risfaheri, Anggraeni, Suprayogi A, Kusumorini N, Winarno W (1997) Production of medicine product from katuk's leaves (Sauropus androgynus (L) Merr) to increase the secretion and quality of breast milk. Integrated Priorities Research (Riset unggulan terpadu II).

8. Sindoeredjo, S. 1960. Pedoman Perusahaan Pemerahan Susu Proyek Pengembangan Produksi Ternak. Direktorat Produksi Peternakan. Direktorat Jendral Peternakan Departemen Pertanian, Jakarta.

9. Soebarinoto S, Chuzaemi, Mashudi (1991) Ilmu Gizi Ruminansia. Universitas Brawijaya, Malang. (Tidak Dipublikasikan).

10. Suprayogi A (2000) Studies on The Biological Effect of Sauropus androgynus (L) Merr : Effect on Milk Production and The Possibilities of Induced Pulmonary Disorder on Lactating Sheep. Cuvilier Verlag, Gottingen. (Disertasi Doktor). 